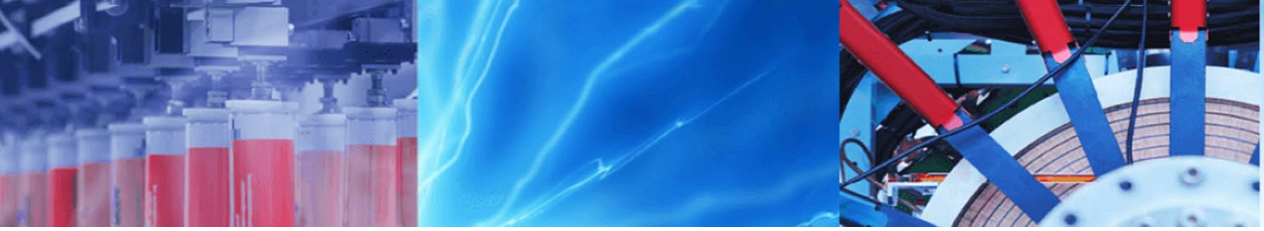

Research Article

\title{
Nitrogen fertilization for wheat following soybean and interfering factors on spectral reflectance readings
}

\author{
Claudio Kapp-Junior ${ }^{1} \cdot$ Alaine Margarete Guimarães ${ }^{2} \cdot$ Eduardo Fávero Caires $^{2} \mathbb{C}$
}

Received: 9 July 2020 / Accepted: 28 September 2020 / Published online: 9 October 2020

(c) Springer Nature Switzerland AG 2020

\begin{abstract}
A field experiment examined the wheat response following soybean due to urea- $\mathrm{N}$ fertilization at sowing $(0,20,40$, and $\left.60 \mathrm{~kg} \mathrm{~N} \mathrm{ha}^{-1}\right)$ and top dressing $\left(0,30,60\right.$, and $\left.90 \mathrm{~kg} \mathrm{~N} \mathrm{ha}^{-1}\right)$. Normalized difference vegetation index (NDVI) measurements using a GreenSeeker active sensor were taken at different growth stages, at various sensor heights above the canopy, and at different times of day. Both the shoot dry matter yield and the grain yield were not affected by $\mathrm{N}$ fertilization at sowing and increased with increasing $\mathrm{N}$ rates at top dressing. A maximum economic yield was obtained at $55 \mathrm{~kg} \mathrm{~N} \mathrm{ha}^{-1}$ in top dressing, causing a 33\% increase in grain yield and an economic return of US\$ $189.50 \mathrm{ha}^{-1}$. Differences in NDVI were found before and after top-dressing $\mathrm{N}$ fertilization, indicating that GreenSeeker was efficient in monitoring wheat $\mathrm{N}$ nutrition. NDVI varied depending on the measurement distance, stabilizing from 0.30 to $1.20 \mathrm{~m}$ above the canopy. Because of the influence of incident radiation, higher NDVI values were obtained at the beginning and end of the day. The results suggest that for the wheat cultivar Quartzo following soybean under minimum soil disturbance, while there is no need to apply $\mathrm{N}$ at sowing, an important increase in grain yield can be obtained with top-dressing $\mathrm{N}$ fertilization. In addition, to improve the accuracy in developing $\mathrm{N}$ fertilizer recommendation models using GreenSeeker, a consistent protocol for spectral reflectance readings, mainly regarding the time of day, is required.
\end{abstract}

Keywords Remote sensing $\cdot$ GreenSeeker $\cdot$ Timing of sensing $\cdot$ Measurement distance $\cdot$ NDVI

\section{Introduction}

Wheat is grown in nearly every region of the world and represents a main source of food and income for millions of farmers. Wheat-based foods are critical for food security and nutritional security worldwide. The main world producers of wheat are the European Union, China, India, Russia, and the USA (USDA 2019). Although Brazilian wheat production is only around 6.0 million $\mathrm{Mg}$, wheat is the main winter crop grown following soybean in southern Brazil.

Wheat has a high nitrogen $(\mathrm{N})$ requirement, and most of the $\mathrm{N}$ is required over a short period, during an exponential growth phase [25]. Usually, the soil supplies a certain amount of $\mathrm{N}$ that depends on the soil organic matter mineralization, but this is not enough to provide all the needs of the plant and additional $\mathrm{N}$ fertilization is required to achieve highest yields [5]. An advantage under the soybean-wheat system is the contribution of the previous legume to reduce the need of $\mathrm{N}$ fertilizer application, since higher rates of decomposition and mineralization of $\mathrm{N}$ can be recycled and recovered by the crop in succession due mainly to the lower residue $\mathrm{C} / \mathrm{N}$ ratio (about 20:1). Anyway, fertilizer $\mathrm{N}$ use is expanding globally to satisfy food demand of a growing world population. However, more than half of the $\mathrm{N}$ added for crop fertilization is currently lost into the environment $[15,30]$. The development of

Eduardo Fávero Caires, efcaires@uepg.br | ${ }^{1} \mathrm{ABC}$ Foundation Agricultural Research and Development, Castro, Parana, Brazil. ${ }^{2}$ State University of Ponta Grossa, Ponta Grossa, Parana, Brazil. 
management practices in agriculture aimed at increasing the $\mathrm{N}$ use efficiency is a worldwide need.

Readings from optical sensors can be associated with important indicators of agricultural crops, such as leaf area index [35], biomass production [18], and grain yield [9]. Thus, the proper use of optical sensors has been useful to improve the production and nutrient use efficiency [10]. Several studies have focused on the development of models for converting indices obtained by reflectance sensors into $\mathrm{N}$ fertilizer rates $[16,26,32]$, without much concern with the development of a consistent protocol for spectral reflectance readings related to interfering factors.

An intended advantage of active optical sensors is that they can take measures at any time of day regardless of variations in solar radiance $[8,13]$. However, sensor readings can be affected directly or indirectly by several factors. Combining light source and measurement distance can result in different spectral reflectance readings [33]. Depending on the measurement distance, the sensor can result in different viewing angles and a chance of footprint size, automatically changing the monitored area $[13,36]$. Factors like weather conditions and time of day [19, 20], photosynthetically active radiation [24], air temperature [13], and daily variations in chlorophyll fluorescence [40] have been highlighted with the possibility of affecting sensor readings. Reflectance patterns can also be strongly affected by factors related to the different stages of plant growth and levels of $\mathrm{N}$ fertilization $[23,27]$.

This study reports a field experiment that examined the effects of $\mathrm{N}$ fertilization at sowing and top dressing on spectral reflectance measurements and shoot dry matter and grain yields of wheat in succession to soybean. During wheat development, spectral reflectance readings using a GreenSeeker sensor were taken at different crop growth stages, at various sensor heights above the canopy, and at different times of day. We hypothesized that $\mathrm{N}$ fertilization causes significant increases in wheat grain yield, even under a soybean-wheat system, and that, although remote sensing can be used to monitor the wheat development to differentiate $\mathrm{N}$ nutrition, the performance of the GreenSeeker active sensor may be compromised if factors like the sensor-plant distance and the time of day for taking readings are not adequately standardized.

\section{Material and methods}

\subsection{Site description and soil}

The experiment was conducted on an Oxisol (clayey, kaolinitic thermic Typic Hapludox) in Palmeira, PR, Brazil $\left(25^{\circ} 23^{\prime} \mathrm{S}, 50^{\circ} 00^{\prime} \mathrm{W}\right)$. Table 1 shows the results of chemical analyses of topsoil $(0-0.20 \mathrm{~m})$ in May 2014 before
Table 1 Results of chemical analyses of the topsoil $(0-0.20 \mathrm{~m})$ in May 2014 before the establishment of the experiment on an Oxisol in Palmeira, PR, southern Brazil

\begin{tabular}{|c|c|}
\hline Attributes & Results \\
\hline $\mathrm{pH}$ (1:2.5 soil:0.01 $\mathrm{m} \mathrm{CaCl}_{2}$ suspension) & 5.2 \\
\hline Total acidity $\mathrm{pH} 7.0(\mathrm{H}+\mathrm{Al})\left(\mathrm{mmol}_{\mathrm{c}} \mathrm{dm}^{-3}\right)$ & 43 \\
\hline Organic matter $\left(\mathrm{g} \mathrm{dm}^{-3}\right)$ & 35 \\
\hline$P\left(\right.$ Mehlich-1) $\left(\mathrm{mg} \mathrm{dm}^{-3}\right)$ & 3.5 \\
\hline Exchangeable cations $\left(\mathrm{mmol}_{\mathrm{c}} \mathrm{dm}^{-3}\right)$ & - \\
\hline $\mathrm{Ca}^{2+}$ & 58 \\
\hline $\mathrm{Mg}^{2+}$ & 28 \\
\hline $\mathrm{K}^{+}$ & 1.3 \\
\hline $\mathrm{Al}^{3+}$ & 0 \\
\hline $\operatorname{ECEC~}\left(\mathrm{mmol}_{\mathrm{c}} \mathrm{dm}^{-3}\right)^{\mathrm{a}}$ & 87.3 \\
\hline CEC pH $7.0\left(\mathrm{mmol}_{\mathrm{c}} \mathrm{dm}^{-3}\right)^{\mathrm{b}}$ & 130.3 \\
\hline Base saturation $(\%)^{c}$ & 67 \\
\hline
\end{tabular}

${ }^{\mathrm{a}}$ Effective cation exchange capacity $(\mathrm{ECEC})=\mathrm{Al}^{3+}+\mathrm{Ca}^{2+}+\mathrm{Mg}^{2+}+$ $\mathrm{K}^{+}$

${ }^{\mathrm{b}}$ Cation exchange capacity (CEC) $\mathrm{pH} 7.0=\mathrm{Ca}^{2+}+\mathrm{Mg}^{2+}+\mathrm{K}^{+}+$total acidity $(\mathrm{H}+\mathrm{Al})$

${ }^{\mathrm{C}}$ Base saturation $=100\left(\mathrm{Ca}^{2+}+\mathrm{Mg}^{2+}+\mathrm{K}^{+} / \mathrm{CEC} \mathrm{pH} 7.0\right)$

the establishment of the experiment. According to Köppen-Geiger system, the climate at the site is categorized as a Cfb type (mesothermal, humid, subtropical), with mild summer and frequent frosts during the winter. The average altitude is $920 \mathrm{~m}$, and the annual rainfall is about $1550 \mathrm{~mm}$. The experiment site had been used for 2 years in a livestock-soybean system using black oat during the winter and with a soybean-wheat system under minimum soil disturbance for the past 5 years.

\section{Experimental design, treatments, and evaluations}

A randomized complete block design was used, with 3 replications in a split-plot arrangement. Four levels of $\mathrm{N}$ fertilization were applied to the plots $(24 \mathrm{~m} \times 6 \mathrm{~m})$ at sowing $\left(0,20,40\right.$, and $\left.60 \mathrm{~kg} \mathrm{ha}^{-1}\right)$, and 4 levels of $\mathrm{N}$ fertilization were applied in top dressing $\left(0,30,60\right.$, and $\left.90 \mathrm{~kg} \mathrm{ha}^{-1}\right)$ to the subplots $(6 \mathrm{~m} \times 6 \mathrm{~m})$, totaling 48 experimental units. Nitrogen was applied as urea.

Wheat (Triticum aestivum L.), cultivar Quartzo, was sown on June 26,2014 , at a density of 350 plants $\mathrm{m}^{-2}$ and row spacing of $0.17 \mathrm{~m}$. Quartzo is a medium-cycle wheat cultivar used for bread-making and indicated for cultivation in the Brazil southern region [14]. Fertilizers at rates of $26 \mathrm{~kg} \mathrm{ha}^{-1} \mathrm{P}$ and $50 \mathrm{~kg} \mathrm{ha}^{-1} \mathrm{~K}$ were applied at sowing. Nitrogen fertilization in top dressing was performed at wheat tillering, at growth stage $Z_{24}$ (main stem and four tillers) on the decimal growth scale of Zadoks 
et al. [39]. The rainfall data registered and the events occurring during the execution of the experiment are presented in Fig. 1. Rainfall was well distributed, and there was no water limitation throughout the development period of the wheat crop. Total rainfall during the wheat cycle amounted to $358 \mathrm{~mm}$. Pest, disease, and weed controls were performed as needed, so as to allow adequate plant development.

The influence of sensor height on spectral reflectance measurements was evaluated by performing readings between 0.10 and $1.20 \mathrm{~m}$ from the plant canopy. A total of 12 height measurements were performed every $0.10 \mathrm{~m}$. Spectral reflectance measurements at the different tested heights were performed at the time of $\mathrm{N}$ application in top dressing (stage $Z_{24}$ ), within a delimited area of $1.0 \mathrm{~m}^{2}(2.0 \mathrm{~m} \times 0.5 \mathrm{~m})$. Since the $N$ fertilization in top dressing had not yet been applied at that time, the subplots consisted of different measuring heights, and the treatments with different $\mathrm{N}$ levels in top dressing were considered as replications.

The influence of the wheat development on spectral reflectance measurements was evaluated by performing readings at the following wheat growth stages, on the decimal growth scale of Zadoks et al. [39]: (1) $Z_{17}$ - seven leaves emerged; (2) $Z_{20}$-main stem only; (3) $Z_{24}$-main stem and four tillers; (4) $Z_{31}$-stem elongation, first node detectable; (5) $Z_{34}$-stem elongation, fourth node detectable; and (6) $Z_{45}$-boots swollen. The measurements were performed at $0.90 \mathrm{~m}$ from the plant canopy within a $3.0 \mathrm{~m}^{2}(3.0 \mathrm{~m} \times 1.0 \mathrm{~m})$ central area of each subplot. Since $\mathrm{N}$ fertilization in top dressing was only applied on $Z_{24}$, measurements performed on $Z_{17}$, $Z_{20}$, and $Z_{24}$ were considered subplots, and treatments with different $\mathrm{N}$ levels in top dressing were considered as replications. After $\mathrm{N}$ rates application in top dressing, subplots consisted of different $\mathrm{N}$ levels in top dressing, and measurements performed at $Z_{31}, Z_{34}$, and $Z_{45}$ were considered sub-subplots.

The influence of the time of day on spectral reflectance measurements was evaluated by performing readings at three different times: (1) from 7:30 to 8:30 am (early morning), (2) from 1 to 2 pm (early afternoon), and (3) from 7 to $8 \mathrm{pm}$ (night). The measurements were performed at $0.90 \mathrm{~m}$ from the plant canopy, on growth stage $Z_{50}$ [first spikelet of inflorescence just visible (Zadoks et. al. 1974)] on an almost cloudless day within a $3.0 \mathrm{~m}^{2}(3.0 \mathrm{~m} \times 1.0 \mathrm{~m})$ central area of each subplot. The different times of day by the early morning, early afternoon, and night were considered sub-subplots. Photosynthetically active radiation was also measured at the same time as the early morning and early afternoon using an AccuPar LP-80 sensor, which has an approximately $0.86-\mathrm{m}$-long probe containing 80 sensors that perform measurements in quanta [34], with a $1 \mu \mathrm{mol} \mathrm{m} \mathrm{m}^{-2} \mathrm{~s}^{-1}$ resolution.

At 120 days after sowing, the plant aerial part was collected in three continuous rows of $4 \mathrm{~m}\left(2.04 \mathrm{~m}^{2}\right)$, and the dry biomass was evaluated to determine shoot dry matter yield. Grain wheat was harvested after crop physiological maturation from a $13.6 \mathrm{~m}^{2}$ area (middle 20 rows by $4.0 \mathrm{~m}$ in length). Grain yield was expressed at $130 \mathrm{~g} \mathrm{~kg}^{-1}$ moisture content. An economic analysis of $\mathrm{N}$ fertilization was conducted using global average prices of the products over the last 10 years [3]. The average price of $\mathrm{N}$ as urea, based on CIF (Cost, Insurance, and Freight) payment, was estimated at US\$ $1150.00 \mathrm{Mg}^{-1} \mathrm{~N}$. The average price of wheat was estimated at US\$240.00 $\mathrm{Mg}^{-1}$ grain. Based on average prices of the products, the ratio of unit cost between $\mathrm{kg}$ of $\mathrm{N}$ and $\mathrm{kg}$ of grain was 4.8 .

\subsection{Active sensor used}

A GreenSeeker 505 Hand Held Optical Sensor was used in our study. This active sensor uses light-emitting
Fig. 1 Weekly rainfall and main events during the wheat development period in the experimental field in 2014

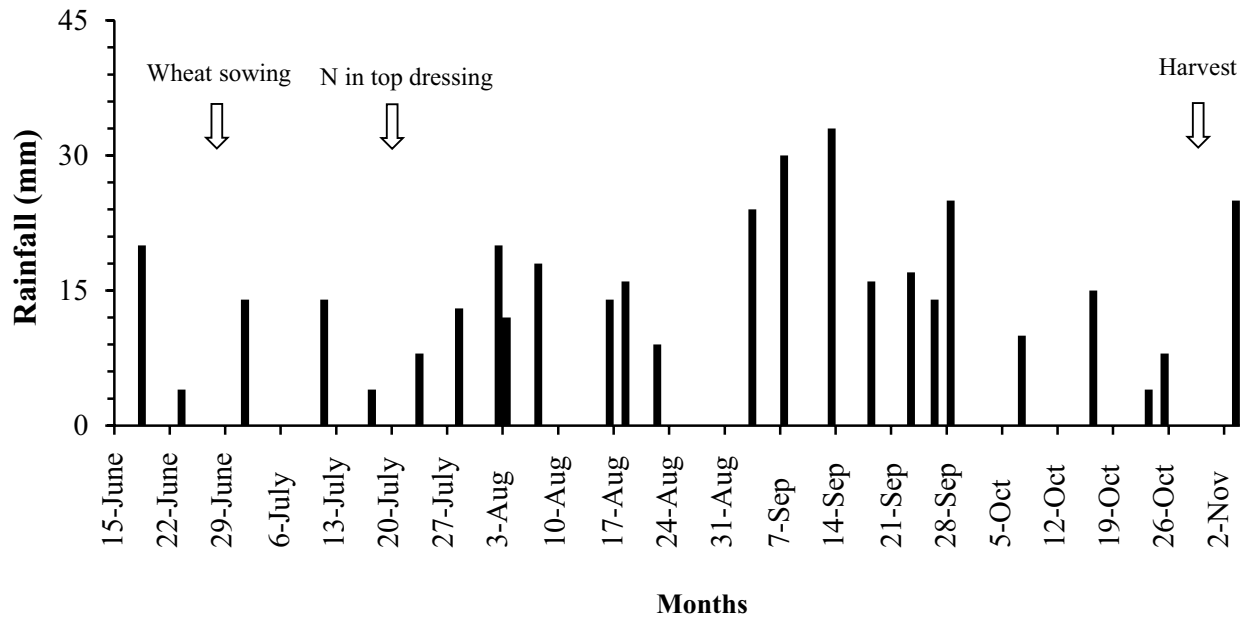

SN Applied Sciences A SPRINGER NATURE journa 
diodes (LEDs) as light source and measures reflectance in the visible (VIS) $(650 \pm 10 \mathrm{~nm})$ and near-infrared (NIR) $(770 \pm 15 \mathrm{~nm})$ regions [6]. The LEDs alternate their pulses, with each emitting 40 light pulses in $1 \mathrm{~ms}$ ( $=40 \mathrm{kHz}$ ) before pausing for the other LED. A single silicon photodiode detector captures the reflected light of both LEDs. The amount of VIS and NIR light reflected by the plant canopy is measured by the sensor and sent to the coupled computer. Angular field of view for the GreenSeeker sensor is not reported by the manufacturer, which indicates that optical masking and position of the sensor LEDs allow the sensor to view a 0.60 -m-wide strip regardless of the sensor height; however, a sensor height of at least $0.80 \mathrm{~m}$ above the target is also recommended. The spectral reflectance measurements are converted to normalized difference vegetation index (NDVI) by the GreenSeeker sensor system [29].

\subsection{Statistical analysis}

Data from the spectral reflectance measurements converted to NDVI and shoot dry matter and grain yields were analyzed through an analysis of variance and regression methods using a randomized complete block design in split-plot or split-split-plot arrangements, depending on the factors and times evaluated. For wheat shoot dry matter and grain yields, the interaction effect of $\mathrm{N}$ rates applied at sowing and top dressing was evaluated. For spectral reflectance measurements, the following interaction effects were evaluated: $N$ rates at sowing $\times$ sensor height, $N$ rates at sowing $\times Z_{17}$, $Z_{20}$, and $Z_{24}$ growth stages, $N$ rates at sowing $\times N$ rates in top dressing $\times Z_{31}, Z_{34}$, and $Z_{45}$ growth stages with their combinations ( $N$ rates at sowing $\times N$ rates in top dressing, $\mathrm{N}$ rates at sowing $\times \mathrm{Z}_{31}, \mathrm{Z}_{34}$, and $\mathrm{Z}_{45}$ growth stages, and $\mathrm{N}$ rates in top dressing $\times Z_{31}, Z_{34}$, and $Z_{45}$ growth stages), and $N$ rates at sowing $\times N$ rates in top dressing $\times$ time of day with their combinations ( $\mathrm{N}$ rates at sowing $\times N$ rates in top dressing, $\mathrm{N}$ rates at sowing $\times$ time of day, and $N$ rates in top dressing $\times$ time of day). In the absence of a significant interaction effect on the variables studied, the data analysis was conducted using the means of the observations. Nitrogen rates applied at sowing and top dressing were analyzed by regression methods, and when the effect was significant at $P<0.05$, the magnitude of the determination coefficients was used as a criterion for choosing the model. The effects of sensor height, plant growth stage, and time of day were compared by the Tukey test at $P=0.05$. Statistical analyses were performed using the R software.

\section{Results and discussion}

\subsection{Effect of $\mathbf{N}$ fertilization on wheat shoot dry matter and grain yields}

Wheat shoot dry matter and grain yields were not significantly influenced by either different $\mathrm{N}$ fertilization levels at sowing, or by interaction of $\mathrm{N}$ rates applied at sowing and top dressing. Increasing $\mathrm{N}$ rates in top dressing linearly increased $(P<0.01)$ shoot dry matter yield (Fig. $2 \mathrm{a})$ and quadratically increased $(P<0.01)$ wheat grain yield (Fig. 2b). Based on the regression equation for grain yield (Fig. 2b), the maximum wheat grain yield $\left(4280 \mathrm{~kg} \mathrm{ha}^{-1}\right)$ would be reached by applying $65 \mathrm{~kg} \mathrm{~N} \mathrm{ha}^{-1}$ in top dressing, and considering the ratio of unit cost between $\mathrm{kg}$ of $\mathrm{N}$ and $\mathrm{kg}$ of grain of 4.8 , the $\mathrm{N}$ rate in top dressing for maximum economic yield $\left(4250 \mathrm{~kg} \mathrm{ha}^{-1}\right)$ was estimated at $55 \mathrm{~kg} \mathrm{ha}^{-1}$. Based on average price of wheat of US\$ 240.00 per $\mathrm{Mg}$ of grain and the average price of $\mathrm{N}$ as urea of US\$ $1150.00 \mathrm{Mg}^{-1} \mathrm{~N}$, the economic return would be US\$ $189.50 \mathrm{ha}^{-1}$ with the $\mathrm{N}$ application rate in top dressing for maximum economic yield $\left(55 \mathrm{~kg} \mathrm{~N} \mathrm{ha}^{-1}\right)$.
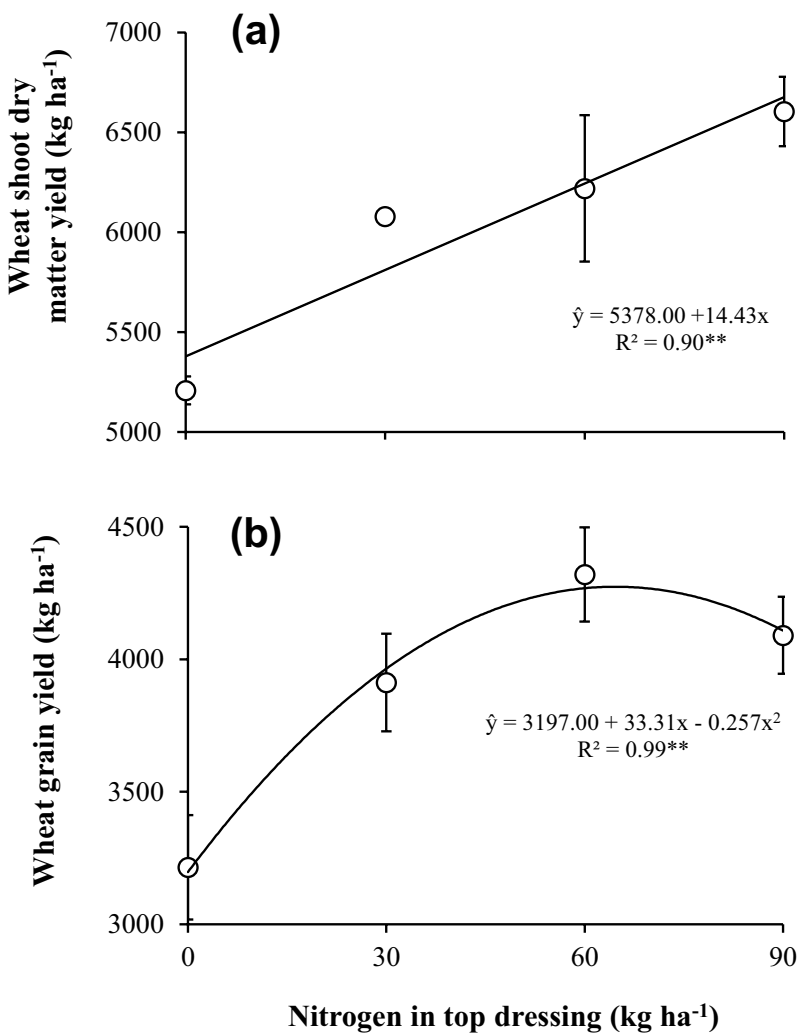

Fig. 2 Wheat shoot dry matter (a) and grain (b) yields as affected by nitrogen rates applied in top dressing at wheat tillering. ${ }^{* *} P<0.01$. The vertical bars indicate the standard error of the mean 
Since the soil $\mathrm{N}$ availability is dependent on mineralization of organic matter [5] and due to the essential role of $\mathrm{N}$ in high-yield systems [7], positive effects of $\mathrm{N}$ fertilization on wheat yields have been frequently observed in studies conducted on Brazilian soils $[11,17,28]$. In our study conducted on an Oxisol with $35 \mathrm{~g} \mathrm{dm}^{-3}$ of organic matter in the topsoil (Table 1), a rate of $55 \mathrm{~kg} \mathrm{~N} \mathrm{ha}^{-1}$ for wheat cultivar Quartzo following soybean provided a maximum economic return to obtain grain yield of $4250 \mathrm{~kg} \mathrm{ha}^{-1}$. Similar results under a soybean-wheat system were found in other studies, with wheat responding economically to the rate of $35 \mathrm{~kg} \mathrm{~N} \mathrm{ha}^{-1}$ for yield around $3100 \mathrm{~kg} \mathrm{ha}^{-1}$ [38], and to the rate of $61.5 \mathrm{~kg} \mathrm{~N} \mathrm{ha}^{-1}$ for yield around $4000 \mathrm{~kg} \mathrm{ha}^{-1}$ [17]. It is true that to provide more appropriate $\mathrm{N}$ recommendations for wheat, our study should have comprised more cultivars, soils, locations, and years. However, the $\mathrm{N}$ rate for maximum economic yield found in our study was consistent with the recommendation of $\mathrm{N}$ fertilization in top dressing for wheat following soybean [22] under highyield systems (3600-4500 kg ha-1) in Parana State, Brazil (51-80 $\left.\mathrm{kg} \mathrm{N} \mathrm{ha}^{-1}\right)$. Although for wheat following soybean, it is recommended to apply $10-30 \mathrm{~kg} \mathrm{~N} \mathrm{ha}^{-1}$ at sowing [22], in our study, there was no need to apply $\mathrm{N}$ at sowing certainly because the soil had a high organic matter content. This result is relevant because the Brazil southern region soils often have higher levels of organic matter due to the predominance of cropping systems with minimum soil disturbance [31].

\subsection{Effect of sensor height on wheat spectral reflectance measurements}

NDVI, obtained from spectral reflectance measurements in wheat, was not significantly influenced by the interaction of sensor heights and $\mathrm{N}$ rates applied at sowing. NDVI, calculated based on reflectance measurements performed when the fourth tiller was emitted (time of $\mathrm{N}$ application in top dressing), linearly increased $(P<0.01)$ with increasing $\mathrm{N}$ rates at sowing (Fig. 3 ). NDVI variations depending on the level of $\mathrm{N}$ fertilization are usually fitted by linear or quadratic equations $[1,11]$. Although wheat shoot dry matter and grain yields at physiological maturation were not affected by the level of $\mathrm{N}$ fertilization at sowing, the $\mathrm{NDVI}$ values showed that $\mathrm{N}$ fertilization at sowing favored the early growth of wheat plants. These results might be related to the better initial development that $\mathrm{N}$ rates at sowing provide wheat plants. In a study by Da Ros et al. [4], it was found that the application of $\mathrm{N}$ in pre-sowing or sowing in a clayey Oxisol increased the availability of $\mathrm{N}$ in the early stages of wheat development, but there were also no effects of this application on the dry above-ground mass and grain yields.

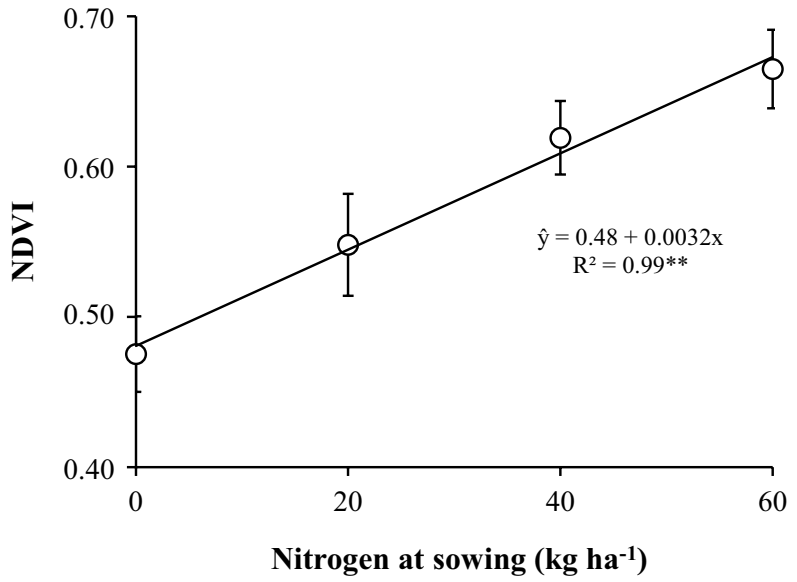

Fig. 3 Mean values of NDVI obtained in the wheat crop at the time of nitrogen fertilization in top dressing $\left(Z_{24}\right.$ stage by Zadoks growth scale) as affected by nitrogen rates applied at sowing. ${ }^{* *} P<0.01$. The vertical bars indicate the standard error of the mean

Table 2 Mean values of NDVI depending on the measuring distance of the GreenSeeker sensor to the wheat plant canopy

\begin{tabular}{ll}
\hline $\begin{array}{l}\text { Measuring height of the sensor relative to the wheat } \\
\text { plant canopy }(\mathrm{m})\end{array}$ & $\mathrm{NDVI}$ \\
\hline 0.10 & $0.82230 \mathrm{a}$ \\
0.20 & $0.76896 \mathrm{a}$ \\
0.30 & $0.59832 \mathrm{~b}$ \\
0.40 & $0.56001 \mathrm{~b}$ \\
0.50 & $0.56403 \mathrm{~b}$ \\
0.60 & $0.56711 \mathrm{~b}$ \\
0.70 & $0.57801 \mathrm{~b}$ \\
0.80 & $0.56843 \mathrm{~b}$ \\
0.90 & $0.57684 \mathrm{~b}$ \\
1.00 & $0.58966 \mathrm{~b}$ \\
1.10 & $0.59636 \mathrm{~b}$ \\
1.20 & $0.58652 \mathrm{~b}$
\end{tabular}

${ }^{*}$ Different letters indicate significant difference by the Tukey test at $P=0.05$

NDVI was also significantly affected by the sensor height from the plant canopy (Table 2). The GreenSeeker manufacturer states that the sensor should be used between 0.80 and $1.20 \mathrm{~m}$ above the canopy. In our study, the closest heights from the canopy resulted in higher NDVI values, causing worsening in the detection of differences in plant development. The NDVI values obtained at 0.10 and $0.20 \mathrm{~m}$ from the plant canopy were not significantly different, but they were higher than the values obtained from 0.30 to $1.20 \mathrm{~m}$ to the canopy. No significant differences in NDVI values were observed for sensor heights from 0.30 to $1.20 \mathrm{~m}$ from the plant canopy. This allows a safety margin for measuring height oscillations. 
Table 3 NDVI values at different wheat growth stages before nitrogen fertilization in top dressing

\begin{tabular}{ll}
\hline Wheat development stage (Zadoks growth scale) & $\mathrm{NDVI}$ \\
\hline $\mathrm{Z}_{17}$ - seven leaves emerged & $0.214 \mathrm{c}$ \\
$\mathrm{Z}_{20}$-main stem only & $0.331 \mathrm{~b}$ \\
$\mathrm{Z}_{24}$-main stem and four tillers & $0.553 \mathrm{a}$ \\
\hline
\end{tabular}

*Different letters indicate significant difference by the Tukey test at $P=0.05$

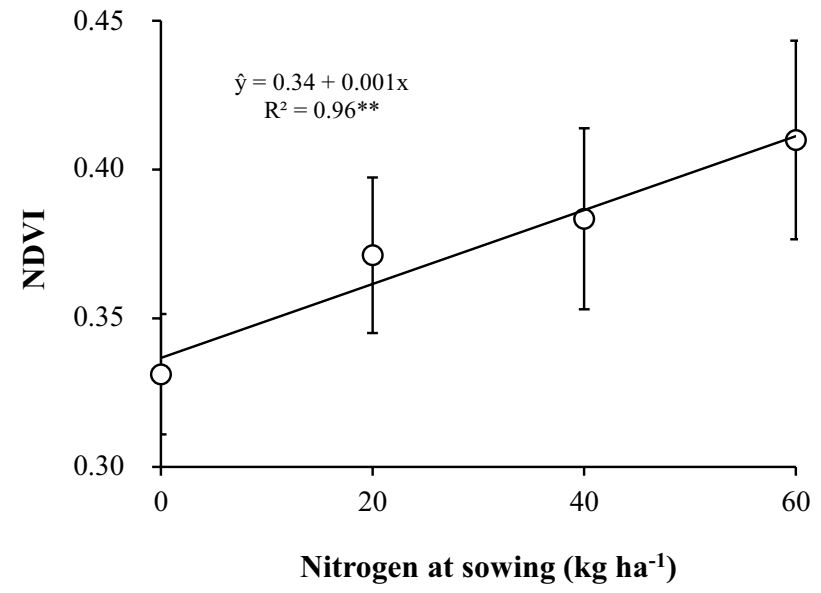

Fig. 4 Mean values of NDVI obtained in the wheat crop at $Z_{17}, Z_{20}$, and $Z_{24}$ stages (Zadoks growth scale), before nitrogen fertilization in top dressing, as affected by nitrogen rates applied at sowing. ${ }^{*} P<0.01$. The vertical bars indicate the standard error of the mean

For example, if the sensor is placed at $1.00 \mathrm{~m}$ from the canopy and it oscillates $\pm 0.20 \mathrm{~m}$ during the displacement of the agricultural machinery, the sensor efficiency would not be negatively affected by resulting variations in NDVI. Similar results were found by Kipp et al. [13], who observed no variations in NDVI values measured between 0.70 and $1.40 \mathrm{~m}$ from the plant canopy. For cotton, the GreenSeeker NDVI predicted an economically optimal $\mathrm{N}$ rate acceptable at the middle of the recommended range $(1.00 \mathrm{~m})$, but performed as well or better at $0.50 \mathrm{~m}$ height [21]. Our results showed that, even with an oscillation of $\pm 0.20 \mathrm{~m}$ (up or down), the sensor could still be placed at $0.50 \mathrm{~m}$ above the canopy of wheat plants, without significantly affecting NDVI values.

\subsection{Effect of wheat growth stage on spectral reflectance measurements}

For NDVI measurements performed before $\mathrm{N}$ fertilization at top dressing in wheat (growth stages $Z_{17}, Z_{20}$, and $Z_{24}$ ), no significant interaction between different measurement times and $\mathrm{N}$ rates applied at sowing was
Table 4 NDVI values at different wheat growth stages after nitrogen fertilization in top dressing

\begin{tabular}{ll}
\hline Wheat development stage (Zadoks growth scale) & $\mathrm{NDVI}$ \\
\hline $\mathrm{Z}_{31}$-stem elongation, first node detectable & $0.718 \mathrm{~b}$ \\
$\mathrm{Z}_{34}$-stem elongation, fourth node detectable & $0.734 \mathrm{~b}$ \\
$\mathrm{Z}_{45}$-boots swollen & $0.782 \mathrm{a}$ \\
\hline
\end{tabular}

${ }^{*}$ Different letters indicate significant difference by the Tukey test at $P=0.05$

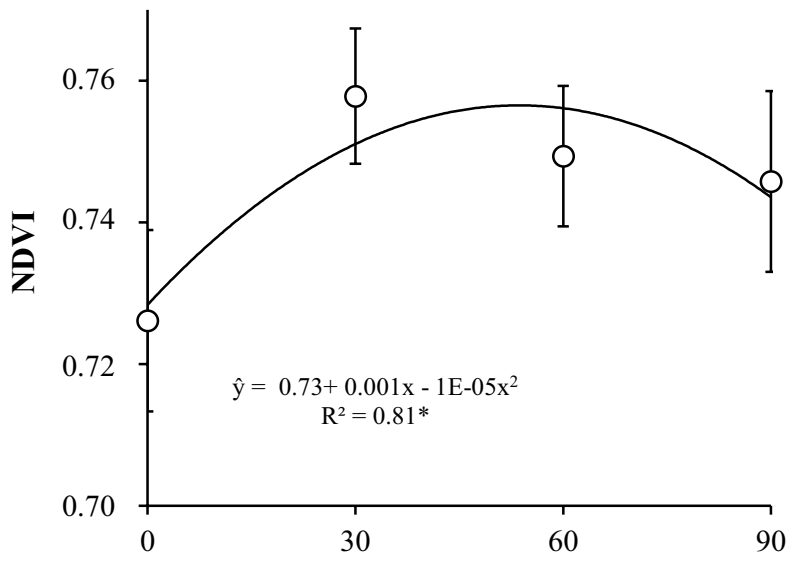

Nitrogen in top dressing $\left(\mathrm{kg} \mathrm{ha}^{-1}\right)$

Fig. 5 Mean values of NDVI obtained in the wheat crop at $Z_{31}, Z_{34}$ and $Z_{45}$ stages (Zadoks growth scale), after applications of nitrogen rates in top dressing. ${ }^{*} P<0.05$. The vertical bars indicate the standard error of the mean

observed. However, NDVI increased as the plant growth stages advanced (Table 3 ) and $\mathrm{N}$ rates applied at sowing increased (Fig. 4).

After applying $\mathrm{N}$ rates at top dressing in wheat (growth stages $Z_{31}, Z_{34}$, and $Z_{45}$ ), NDVI was also not affected by the interactions of different measurement times and levels of $\mathrm{N}$ fertilization. Spectral reflectance measurements were not affected by $\mathrm{N}$ rates applied at sowing. However, NDVI was significantly influenced by the plant growth stage (Table 4), and by the levels of $\mathrm{N}$ fertilization at top dressing (Fig. 5). At $Z_{45}$ stage, NDVI was significantly higher than $Z_{31}$ and $Z_{34}$ stages (Table 4 ). NDVI was also raised with the application of $\mathrm{N}$ rates in top dressing $(P<0.05)$, exhibiting a quadratic response (Fig. 5). The adjusted regression equation showed that the highest mean value of NDVI at $Z_{31}$, $Z_{34}$, and $Z_{45}$ stages would be reached with $\mathrm{N}$ fertilization in top dressing at $50 \mathrm{~kg} \mathrm{~N} \mathrm{ha}^{-1}$, whose rate was close to that obtained for maximum economic yield $\left(55 \mathrm{~kg} \mathrm{~N} \mathrm{ha}^{-1}\right)$. Similar results related to changes in NDVI depending on the level of $\mathrm{N}$ fertilization and plant development stage were found by Rissini et al. [27]. 


\subsection{Influence of the time of day on wheat spectral reflectance measurements}

Increasing $\mathrm{N}$ rates in top dressing linearly increased NDVI $(P<0.01)$ measured on growth stage $Z_{50}$ (first spikelet of inflorescence just visible) (Fig. 6).

Photosynthetically active radiation increased approximately $6 \mu \mathrm{mol} \mathrm{m} \mathrm{m}^{-2} \mathrm{~s}^{-1}$ per minute during the early morning, varying from $540 \mu \mathrm{mol} \mathrm{m}{ }^{-2} \mathrm{~s}^{-1}$ at 7:30 am to $900 \mu \mathrm{mol} \mathrm{m}^{-2} \mathrm{~s}^{-1}$ at approximately 8:30 am (Fig. 7a). During the early afternoon, photosynthetically active radiation was measured when it was already decreasing, at approximately $2.15 \mu \mathrm{mol} \mathrm{m} \mathrm{m}^{-2} \mathrm{~s}^{-1}$ per minute, going from $1750 \mu \mathrm{mol} \mathrm{m}^{-2} \mathrm{~s}^{-1}$ at $1 \mathrm{pm}$ to $1620 \mu \mathrm{mol} \mathrm{m}^{-2} \mathrm{~s}^{-1}$ at approximately 2 pm (Fig. 7b). Photosynthetically active radiation can reach approximately $2000 \mu \mathrm{mol} \mathrm{m} \mathrm{m}^{-2} \mathrm{~s}^{-1}$ on a sunny day and be greater at higher altitudes [34]. No photosynthetically active radiation incidence was measured at night (from 7 to $8 \mathrm{pm}$ ).

Significant differences in NDVI were observed at different times of day, in the following descending order: from 7 to $8 \mathrm{pm}>$ from 7:30 to 8:30 am > from 1 to $2 \mathrm{pm}$ (Table 5). Our results indicate that NDVI was highest when photosynthetically active radiation was lowest, which closely agree with observations by Allen et al. [2], who demonstrated that short-term reductions in solar radiation due to a cloud covering the sun were repeatedly associated with an immediate increase in GreenSeeker NDVI. Kim et al. [12] also found a slight decrease in GreenSeeker NDVI as ambient light level increased in a controlled environment. Allen et al. [2] measured GreenSeeker NDVI from cotton nine times during the course of a day and found that the average NDVI values were about $4 \%$ higher $4 \mathrm{~h}$ before and

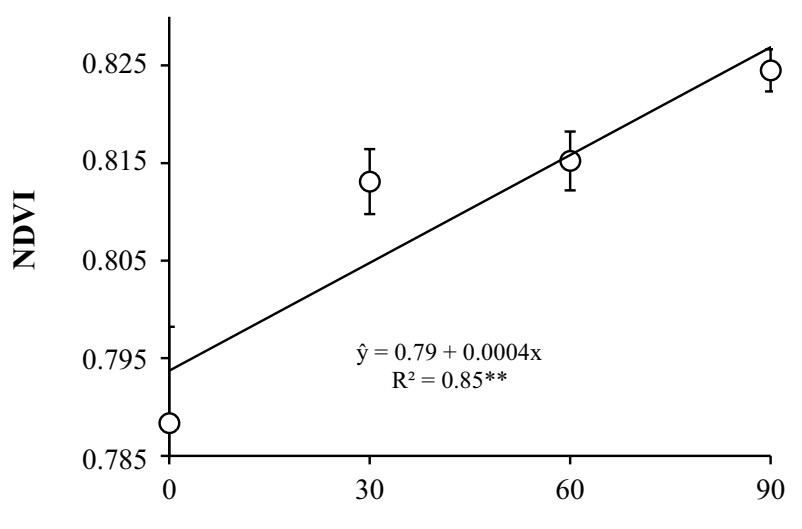

Nitrogen in top dressing $\left(\mathrm{kg} \mathrm{ha}^{-1}\right)$

Fig. $6 \mathrm{NDVI}$ values obtained in the wheat crop at $Z_{50}$ stage (first spikelet of inflorescence just visible by Zadoks growth scale) as affected by nitrogen rates applied in top dressing. ${ }^{* *} P<0.01$. The vertical bars indicate the standard error of the mean

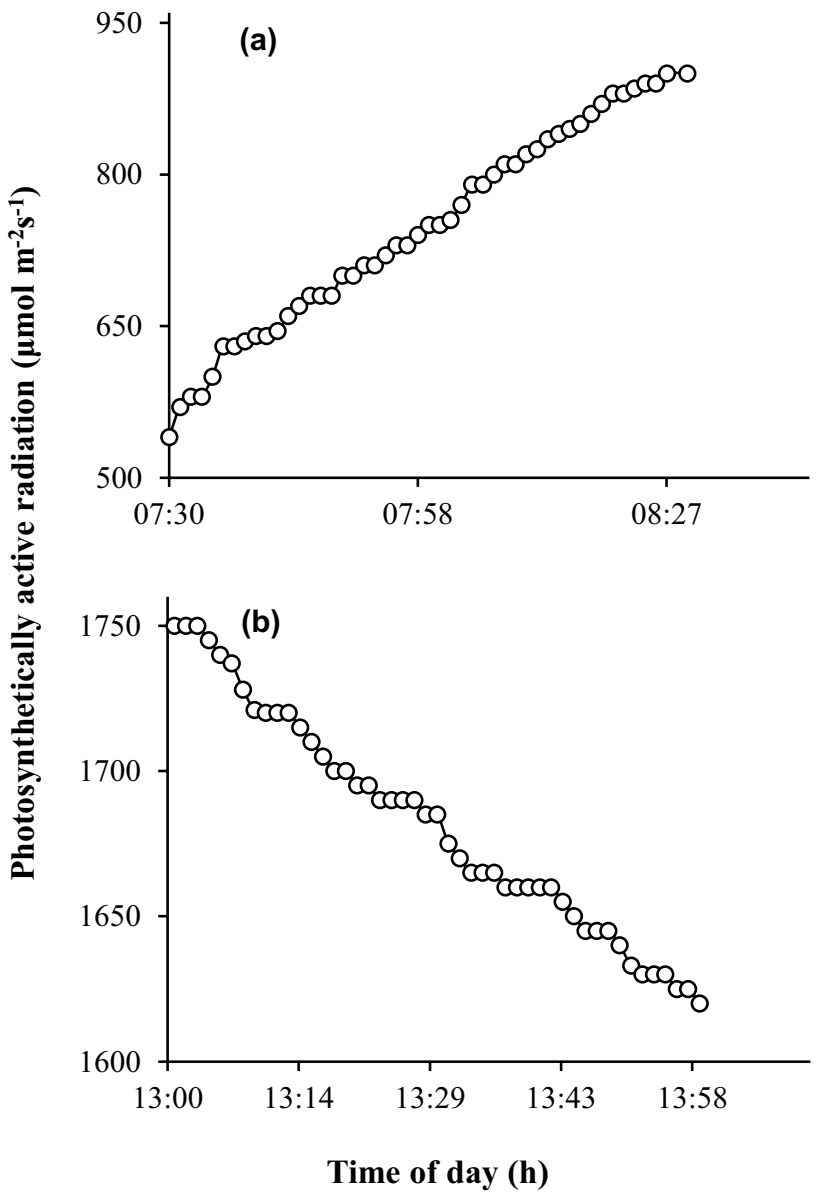

Fig. 7 Photosynthetically active radiation during the early morning (a) and early afternoon (b) in wheat experiment

after noon than at noon. In a study by Oliveira and Scharf [20], the highest NDVI values from cotton using the GreenSeeker sensor were also measured early and late in the day. In our study, GreenSeeker NDVI values were 3 and 5\% higher from 7:30 to 8:30 am and from 7 to $8 \mathrm{pm}$ than from 1 to $2 \mathrm{pm}$, respectively. Oliveira and Scharf [20] suggest that GreenSeeker sensor is the source of this variation and the behavior of the sensor is influenced by environmental conditions. Because photosynthetically active radiation indirectly affects NDVI due to its natural relationship with

Table 5 NDVI readings from wheat canopy according to timing of sensing within a day

\begin{tabular}{lll}
\hline Period & Timing of sensing (h) & NDVI \\
\hline Early morning & $7: 30$ to $08: 30 \mathrm{am}$ & $0.813 \mathrm{~b}$ \\
Early afternoon & 1 to $2 \mathrm{pm}$ & $0.788 \mathrm{c}$ \\
Night & 7 to $8 \mathrm{pm}$ & $0.830 \mathrm{a}$ \\
\hline
\end{tabular}

${ }^{*}$ Different letters indicate significant difference by the Tukey test at $P=0.05$ 


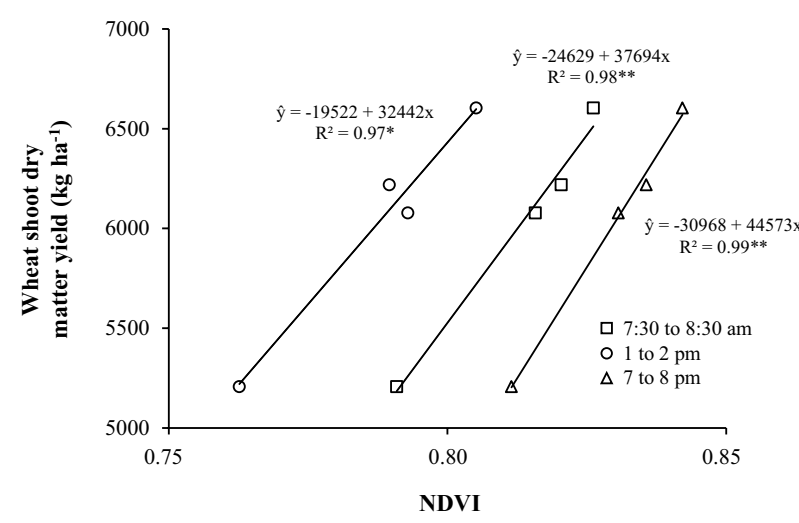

Fig. 8 Wheat shoot dry matter yield as affected by NDVI values obtained during the early morning (7:30 to $8: 30 \mathrm{am})$, early afternoon ( 1 to $2 \mathrm{pm}$ ), and at night ( 7 to $8 \mathrm{pm}$ ). ${ }^{* *} P<0.01$ and ${ }^{*} P<0.05$

ambient temperature [24], GreenSeeker NDVI may not have been directly affected by photosynthetically active radiation through its effect on spectral reflectance [13]. In addition, the ambient temperature can affect device temperature and it influences the quality of the different light-emitting diodes affecting sensor readings [13].

Wheat shoot dry matter yield was linearly correlated to NDVI (Fig. 8), with coefficients of determination $\left(R^{2}\right)$ of 0.99 $(P<0.01), 0.98(P<0.01)$, and $0.97(P<0.05)$ for measurements performed from 7 to $8 \mathrm{pm}$, from 7:30 to $8: 30 \mathrm{am}$, and from 1 to $2 \mathrm{pm}$, respectively. Because all measurements were performed within the same area and the same height from the plant canopy, differences were likely due to different times of sensing within a day. Unlike previous studies with wheat reporting that canopy reflectance measurements were not affected by the time of day and solar radiation $[8,13]$, in our study we found that, in view of the influence of incident radiation, the time of day could cause distortions in GreenSeeker NDVI values. Such reading distortions could result in large differences in the practical situations of using this technology. For example, if the sensor is used for $\mathrm{N}$ fertilization recommendation, as in Raun et al. [26], the lack of care with the timing of sensing, depending on the incident radiation, could distort the spectral reflectance readings and, consequently, the NDVI, resulting in over- or underestimation of the optimal $\mathrm{N}$ rate to be applied to the wheat crop.

\section{Conclusion}

Under a soybean-wheat system established on an Oxisol with $35 \mathrm{~g} \mathrm{dm}^{-3}$ of organic matter in the topsoil, both the shoot dry matter yield and the wheat grain yield cultivar Quartzo were not affected by $\mathrm{N}$ fertilization at sowing, although they were increased with $\mathrm{N}$ fertilization in top dressing. The maximum yield $\left(4280 \mathrm{~kg} \mathrm{ha}^{-1}\right)$ and the maximum economic yield $\left(4250 \mathrm{~kg} \mathrm{ha}^{-1}\right)$ of wheat were achieved when applying $\mathrm{N}$ in top dressing at 65 and $55 \mathrm{~kg} \mathrm{ha}^{-1}$, respectively. An increase by $33 \%$ in grain yield and an economic return of US\$ $189.50 \mathrm{ha}^{-1}$ were obtained applying $\mathrm{N}$ in top dressing at the rate of maximum economic yield. GreenSeeker NDVI measurements varied depending on the sensor height, stabilizing from 0.30 to $1.20 \mathrm{~m}$ above the canopy. So, even with an oscillation of $\pm 0.20 \mathrm{~m}$ during the displacement of the agricultural machinery, the sensor could be placed at least $0.5 \mathrm{~m}$ above the wheat canopy, without significantly affecting its performance. Different NDVI values were observed for different wheat growth stages, before and after $\mathrm{N}$ fertilization in top dressing, indicating that GreenSeeker was efficient in monitoring wheat development to differentiate $\mathrm{N}$ nutrition. However, higher NDVI values were measured at times of day with lower incident radiation (from 7 to $8 \mathrm{pm}>$ from 7:30 to $8: 30$ am > from 1 to $2 \mathrm{pm}$ ). Thus, to improve the accuracy in developing $\mathrm{N}$ fertilizer recommendation models using GreenSeeker, a consistent protocol for spectral reflectance readings, mainly regarding the time of day, is required.

Funding This study was funded by Brazilian Council for Scientific and Technological Development (CNPq) (Grant Number 309669/2017-0).

\section{Compliance with ethical standards}

Conflict of interest The authors declare that they have no conflict of interest.

\section{References}

1. Ali AM, Thind HS, Varinderpal-Singh B-S (2015) A framework for refining nitrogen management in dry direct-seeded rice in using GreenSeeker ${ }^{\mathrm{TM}}$ optical sensor. Comput Electron Agric 110:114-120. https://doi.org/10.1016/j.compag.2014.10.021

2. Allen PB, Wilkerson JB, Ramirez MB (2009) Evaluating temporal variation in active-light plant sensors. In: Boyd S et al (eds) Proceedings 2009, Beltwide cotton conferences, San Antonio TX, 5-8 Jan 2009. Natl Cotton Council Am, Memphis, TN, p 367-373

3. Caires EF, Garbuio FJ, Churka S, Joris HAW (2011) Use of gypsum for crop grain production under a subtropical no-till cropping system. Agron J 103:1804-1814. https://doi.org/10.2134/agron j2011.0192

4. Da Ros CO, Salet RL, Porn RL, Machado JNC (2003) Disponibilidade de nitrogênio e produtividade de milho e trigo com diferentes métodos de adubação nitrogenada no sistema plantio direto [Effects of fertilization methods on soil nitrogen availability for wheat and corn production]. Cienc Rural 33:799-804. https://doi.org/10.1590/S0103-84782003000500002

5. Dourado-Neto D, Powlson D, Abu-Bakar R, Bacchi OOS, Basanta MV, Cong PT, Keerthisinghe G, Ismaili M, Rahman SM, Reichardt K, Safwat MSA, Sangakkara R, Timm LC, Wang JY, 
Zagal E, van Kessel C (2010) Multiseason recoveries of organic and inorganic nitrogen-15 in tropical cropping systems. Soil Sci Soc Am J 74:139-152. https://doi.org/10.2136/sssaj 2009.0192

6. Erdle K, Mistele B, Schimidhalter U (2011) Comparison of active and passive spectral sensors in discriminating biomass parameters and nitrogen status in wheat cultivars. Field Crops Res 124:74-84. https://doi.org/10.1016/j.fcr.2011.06.007

7. Fageria NK (2014) Nitrogen management in crop production. CRC Press, New York

8. Fitzgerald GJ (2010) Characterizing vegetation indices derived from active and passive sensors. Int J Remote Sens 31:43354348. https://doi.org/10.1080/01431160903258217

9. Guo C, Tang Y, Lu J, Zhu Y, Cao W, Cheng T, Zhang L, Tian Y (2019) Predicting wheat productivity: integrating time series of vegetation indices into crop modeling via sequential assimilation. Agric For Meteorol 272-273:69-80. https://doi.org/10.1016/j. agrformet.2019.01.023

10. Hedley C (2014) The role of precision agriculture for improved nutrient management on farms. J Sci Food Agric 95:12-19. https ://doi.org/10.1002/jsfa.6734

11. Kapp Junior C, Caires EF, Guimarães AM (2014) Discriminating biomass and nitrogen status in wheat crop by spectral reflectance using artificial neural networks. Int J Agric Environ Inf Syst 5:38-49. https://doi.org/10.4018/IJAEIS.2014040103

12. Kim Y, Glenn DM, Park J, Ngugi HK, Lehman BL (2012) Characteristics of active spectral sensor for plant sensing. Trans ASABE 55:293-301. https://doi.org/10.13031/2013.41239

13. Kipp S, Mistele B, Schmidhalter U (2014) The performance of active spectral reflectance sensors as influenced by measuring distance, device temperature and light intensity. Comput Electron Agric 100:24-33. https://doi.org/10.1016/j.compa g.2013.10.007

14. Kuhnem P, Rosa AC, Wagner F, Rosa ATS (2020) Informações técnicas para trigo e triticale: safra 2020 (Technical information for wheat and triticale: 2020 season). Biotrigo Genética, Passo Fundo

15. Lassaletta L, Billen G, Grizzetti B, Anglade J, Garnier J (2014) 50 year trends in nitrogen use efficiency of world cropping systems: the relationship between yield and nitrogen input to cropland. Environ Res Lett 9:1-9. https://doi.org/10.1088/17489326/9/10/105011

16. Limon-Ortega A (2009) Wheat grain yield response to $\mathrm{N}$ application evaluated through canopy reflectance. Cereal Res Commun 37:595-601. https://doi.org/10.1556/CRC.37.2009.4.14

17. Los Galetto S, Bini AR, Haliski A, Scharr DA, Borszowskei PR, Caires EF (2017) Nitrogen fertilization in top dressing for wheat crop in succession to soybean under a no-till system. Bragantia 76:282-291. https://doi.org/10.1590/1678-4499.095

18. Ma J, Li Y, Chen Y, Du K, Zheng F, Zhang L, Sun Z (2019) Estimating above ground biomass of winter wheat at early growth stages using digital images and deep convolutional neural network. Eur J Agron 103:117-129. https://doi.org/10.1016/j. eja.2018.12.004

19. Martins RN, Moraes HMF, Portes MF, Orlando Junior WA (2020) Ribeiro Junior MF (2020) Do optical sensor readings change throughout the day? An evaluation of two sensor systems. J Plant Nutr. https://doi.org/10.1080/019041671739296

20. Oliveira LF, Scharf PC (2014) Diurnal variability in reflectance measurements from cotton. Crop Sci 54:1769-1781. https://doi. org/10.2135/cropsci2013.04.0217

21. Oliveira LF, Scharf PC, Vories ED, Drummond ST, Dunn D, Stevens WG, Bronson KF, Benson NR, Hubbard VC, Jones AS (2013) Calibrating canopy reflectance sensors to predict optimal midseason nitrogen rate for cotton. Soil Sci Soc Am J 77:173-183. https://doi.org/10.2136/sssaj2012.0154
22. Pauletti V, Motta ACV (2017) Manual de adubação e calagem para o Estado do Paraná (Fertilization and liming manual for the Paraná State). Sociedade Brasileira de Ciência do Solo, Núcleo Estadual Paraná, Curitiba

23. Qiao K, Zhu W, Xie Z, Li P (2019) Estimating the seasonal dynamics of the leaf area index using piecewise LAI-VI relationships based on phenophases. Remote Sens 11:689. https://doi. org/10.3390/rs11060689

24. Rahman MM, Lamb DW, Stanley JN (2015) The impact of solar illumination angle when using active optical sensing of NDVI to infer fAPAR in a pasture canopy. Agric For Meteorol 202:39-43. https://doi.org/10.1016/j.agrformet.2014.12.001

25. Raun WR, Johnson GV (1999) Improving nitrogen use efficiency for cereal production. Agron J 91:357-363. https://doi. org/10.2134/agronj1999.00021962009100030001x

26. Raun WR, Solie JB, Johnson GB, Stone ML, Mullen RW, Freman $\mathrm{KW}$, Thomason WE, Lukina EV (2002) Improving nitrogen use efficiency in cereal grain production with optical sensing and variable rate application. Agron J 94:815-820. https://doi. org/10.2134/agronj2002.8150

27. Rissini ALL, Kawakami J, Genú AM (2015) Índice de vegetação por diferença normalizada e produtividade de cultivares de trigo submetidas a doses de nitrogênio (Normalized difference vegetation index and yield of wheat cultivars under different application rates of nitrogen). Rev Bras Cienc Solo 39:17031713. https://doi.org/10.1590/01000683rbcs20140686

28. Rodrighero $M B$, Caires EF, Lopes RB, Zielinski AA, Granato D, Demiate IM (2015) Wheat technological quality as affected by nitrogen fertilization under a no-till system. Acta Sci Technol 37:175-181. https://doi.org/10.4025/actascitechnol.v37i1.21113

29. Rouse JW, Haas RH, Schell JA, Deering DW (1974) Monitoring vegetation systems in the Great Plains with ERTS. In: proceedings third ERTS-1 symposium, NASA Goddard, NASA SP-35, $\mathrm{p}$ 309-317

30. Snyder CS, Davidson EA, Smith P, Venterea RT (2014) Agriculture: sustainable crop and animal production to help mitigate nitrous oxide emissions. Curr Opin Env Sust 9-10:46-54. https ://doi.org/10.1016/j.cosust.2014.07.005

31. Sá JCM, Tivet F, Lal R, Briedis C, Hartman DC, Santos JZ, Santos JB (2014) Long-term tillage systems impacts on soil C dynamics, soil resilience and agronomic productivity of a Brazilian Oxisol. Soil Till Res 136:38-50. https://doi.org/10.1016/j.still.2013.09.010

32. Solie JB, Monroe AD, Raun WR, Stone ML (2012) Generalized algorithm for variable-rate nitrogen application in cereal grains. Agron J 104:378-387. https://doi.org/10.2134/agronj2011.0249

33. Stocker VS, Souza EG, Johan JA, Bneduzzi HM, Silva SO (2019) Effect of height, tilt and twist angles of an active reflectance sensor on NDVI measurements. Eng Agríc 39:96-108. https:// doi.org/10.1590/1809-4430-eng.agric.v39nep96-108/2019

34. Taiz L, Zeiger E (2006) Fisiologia Vegetal [Plant physiology]. Artmed, Porto Alegre

35. Tan C, Zhang P, Zhou X (2020) Quantitative monitoring of leaf area index in wheat of different plant types by integrating NDVI and Beer-Lambert law. Sci Rep 10:929. https://doi.org/10.1038/ s41598-020-57750-z

36. Tubana B, Harrell D, Walker T, Teboh J, Lofton J, Kanke Y, Philips $S$ (2011) Relationships of spectral vegetation indices with rice biomass and grain yield at different sensor view angles. Agron J 103:1405-1413. https://doi.org/10.2134/agronj2011.0061

37. United States Department of Agriculture (2019) World agricultural supply and demand estimates. USDA, Washington

38. Wendling A, Eltz FLF, Cubilla MM, Amado TJC, Mielniczuk J, Lovato T (2007) Recomendação de adubação nitrogenada para trigo em sucessão ao milho e soja sob sistema plantio direto no Paraguai [Nitrogen fertilizer recommendation for no-till wheat in succession to corn and soybean in Paraguay]. Rev Bras Cienc 
Solo 31:985-994. https://doi.org/10.1590/S0100-0683200700 0500015

39. Zadoks JC, Chang TT, Konzak CF (1974) A decimal code for the growth stages of cereals. Weed Res 14:415-421. https://doi. org/10.1111/j.1365-3180.1974.tb01084.x

40. Zarco-Tejada PJ, Miller JR, Mohammed GH, Noland TL (2000) Chlorophyll fluorescence effects on vegetation apparent reflectance: I. Leaf-level measurements and model simulation.
Remote Sens Environ 74:582-595. https://doi.org/10.1016/ S0034-4257(00)00148-6

Publisher's Note Springer Nature remains neutral with regard to jurisdictional claims in published maps and institutional affiliations. 